\title{
Effect of Methanol Leaf Extract of Vitex Doniana on Cadmium Chloride-Induced Toxicity in Kidney and Liver Tissues of Male Wistar Rats
}

\author{
Olajide, J. E., Sanni, M., Omattah, G. O. \\ Department of Biochemistry, Faculty of Natural Sciences, \\ Kogi State University, Anyigba, Kogi State, Nigeria
}

\section{ABSTRACT}

The aim of this study was to investigate the effects of methanol leaf extract of Vitex doniana (MEVd) on Cadmium chloride - induced toxicity in the liver and kidney of male Wistar rats was investigated. Twenty five male Wistar rats weighing $171.87 \pm 7.86 \mathrm{~g}$ were acclimatized for two weeks and subsequently randomized into five groups: Group 1 rats were administered daily $1 \mathrm{ml}$ distilled water (control group); group 2 were administered Cadmium chloride (10 $\mathrm{mg} / \mathrm{kg}$ b.w.) only; groups $3 /$ and $/ 4$ were administered MEVd (200 and $400 \mathrm{mg} / \mathrm{kg}$ b.w. respectively) six hours prior administration of $\mathrm{Cd}$ (10 $\mathrm{mg} \mathrm{Cd} / \mathrm{kg} \mathrm{b.w.)} \mathrm{and} \mathrm{group} 5$ rats were administered MEVd (400 mg/kg/b.w.) only. The experiment lasted six weeks and all administration was carried out orally. The final body weights of the rats were recorded at the end of the experiment and afterwards the rats were sacrificed, blood was collected and the serum was subsequently prepared. The kidneys and liver were excised, weighed and then stored in $10 \%$ formalin for histological examination. The serum was used for the determination of urea, creatinine, $\mathrm{Na}$, $\mathrm{K}+$ and $\mathrm{Cl}-$ concentrations, aspartate aminotransferase (AST) and alanine aminotransferase (ALT) activities and total bilirubin (T-Bil) concentration. The results showed that exposure of the rats to $\mathrm{Cd}$ significantly $(\mathrm{p}<0.05)$ increased kidney weight, serum urea, creatinine, $\mathrm{Na}+, \mathrm{K}+, \mathrm{Cl}-$ and total bilirubin concentrations as well as serum ALT and AST activities. Cd-induced toxicity also caused severe necrosis of the tubular epithelial cells in the nephrons and degeneration of the hepatocytes. Although both doses of the plant extract significantly ameliorated these changes, the amelioration at 200 $\mathrm{mg} / \mathrm{kg}$ body weight of the extract compared well with the control in most of the parameters investigated. In conclusion, the oral administration of methanol leaf extract of Vitex doniana ameliorated the Cd-induced toxicity related biochemical parameters and histological changes in the rats.

Keyword: Cadmium chloride, Toxicity, Liver, Kidney, Vitex doniana, Ameliorate

\section{INTRODUCTION}

Cadmium (Cd) is one of the most notorious toxic heavy metals. It is one of the major toxic environmental and industrial pollutants, obtained through consumption of $\mathrm{Cd}$ contaminated foods, drinking water, inhaled air, cigarette or from ingestion of polluted soil and dust (Jarup et al., 2000). Cd is generally used as components of pigments, plastic stabilizers, alloys, Nickel-Cd batteries, and in welding and electroplating in industries. It is also present in tobacco grown on contaminated soil (Ohta et al. 2000; Washington et al., 2006). Cd is spread from its natural sources into the atmosphere through volcanic activity, forest fires, and wind-blown soil particles. Other sources of $\mathrm{Cd}$ include phosphate fertilizers, which may possess high levels of Cd based on the origin of the rock, and also the use of contaminated sewage sludge as soil additive (Waisberg et al., 2003). Being that polyvinyl chloride (PVC) contains cadmium, toys made of PVC are potentially toxic to children. Owing to its long biological half-life of 15-30 years, the rate of disintegration of cadmium is very low; and as a result, cadmium accumulates in the blood, kidneys, liver and reproductive organs, such as placenta, testis as well as the ovaries, making it a hazardous toxic metal (Navaneethan and Rasool, 2014). However, the kidney is the primary target organ for chronic lowlevel exposure to $\mathrm{Cd}$ and is reflected in a number of 
renal function parameters including tubular necrosis (Satarug et al., 2010). This may eventually result to end-stage renal failure, abnormal blood pressure, diabetic manifestations and osteoporosis (Satarug and Moore, 2004).

In recent time, there is an increasing interest in herbal formulations because of their potent antioxidant properties. Higher intake of vegetables, fruits and whole grains that are rich in antioxidants have been associated to reduce risk of several diseases, including cancer, cardiac diseases, chronic inflammation and many degenerative diseases. Vitex doniana ( $V$. doniana), a member of the Verbanaceae family is a perenial shrub with wide distribution in tropical West Africa such as Nigeria, and extends to some East African countries and in the savannah and high rainfall areas (Atawodi et al., 2003). V. doniana leaves are consumed in Nigeria as vegetables which are valued sources of protective foods and it is of great benefits for the maintenance of good health and disease prevention (Nnamani et al., 2007). In ethnomedicine, $V$. doniana leaf is utilized in the management and treatment of many diseases. It is employed in the treatment of stomach and rheumatic pains, inflammatory disorders, diarrhoea and dysentery (Iwueke et al., 2006). According to Iwu (1993), the leaves and roots of $V$. doniana are also utilized in the treatment of nausea, colic and epilepsy. The plant has been utilized as medication for liver disease, anodyne, stiffness, leprosy, backache, hemiplegia, conjunctivitis, rash, measles, rachitis and febrifuge. It also serve as tonic galactagogue to aid milk production in nursing mothers, sedative, digestive regulator and treatment of eye and kidney problems, and as supplement for lack of vitamin A and B (Burkill, 2000). A number of authors have evaluated the medicinal/pharmacological application of Vitex doniana: antioxidant and hypoglycaemic (Yakubu et al., 2013) antimicrobial (Nwachukwu and Uzoeto, 2010), anti-inflammatory and analgesic (Iwueke et al., 2006) effects. Phytochemical reports abound to show that $V$. doniana extracts contains secondary metabolites and other phytochemicals such as alkaloids, saponins, tannins, anthraquinones, flavonoids, terpenoids which account for its therapeutic potential (Agbafor and Nwachukwu, 2011). The aim of this study was to investigate the ameliorative effect of methanol leaf extract of Vitex doniana in Cadmium chloride-induced toxicity in the kidney and liver of male Wistar rats.

\section{Materials and methods}

\section{Chemicals, reagents and equipment}

Reagents: The reagents used for this study was purchased from reputable companies. Reagent kits for urea, creatinine, ALT, AST and bilirubin assays are products of Randox Laboratories Ltd., United Kingdom. Reagent sets for sodium, potassium and chloride concentrations assays are products of Teco Diagnostics, U.S.A.

\section{Collection and extraction of Vitex doniana leaves}

Fresh leaves of Vitex doniana were collected in the vicinity of Kogi State University Anyigba, Nigeria. They were thereafter authenticated in the Department of Biological Sciences, Kogi State University, Anyigba, Nigeria. The plant leaves were rinsed in water, air dried and pulverized to fine particles. To obtain the methanol leaf extract of Vitex doniana $(\mathrm{MEVd}), 1000 \mathrm{~g}$ of the plant material were soaked in 3 litres of methanol for 48 hours. The filteration process was done using a filter paper (Whatman grade $1)$ and vacuum pump. The extract was concentrated at $40^{\circ} \mathrm{C}$ using a rotary evaporator (RV 05 basic, Germany) and water bath (HH-W420, England) to dryness. The crude extracts obtained was stored in capped vials at $4^{\circ} \mathrm{C}$.

\section{Animals}

Adult male wistar albino rats of body weight ranging from $171 \pm 7.86 \mathrm{~g}$ were obtained from the animal breeding and care facility of Federal University Lokoja, Nigeria. The animals were kept in standard rat cages at room temperature $\left(25 \pm 2^{\circ} \mathrm{C}\right)$ with a normal 12-hour light/dark cycle and received standard commercial pelleted rat chow and water ad libitum. The rats were housed in the animal house facility of Department of Biochemistry, Kogi State University, Nigeria. Handling and treatments of rats was in conformity with standard guideline for laboratory animal care and use. The rats were allowed to acclamatiize for a period of 14 days.

\section{Treatment and grouping of experimental animals}

Cadmium was dissolved in distilled water and orally given to the male wistar albino rats at a dose of 10 $\mathrm{mg} / \mathrm{kg}$ body weight (b.wt) (Al-Hashem et al., 2009) using a feeding needle. The Vitex doniana extract (MEVd) was dissolved in distilled water. Cadmium was administered in groups II, III and IV.

Twenty five male Wistar rats were randomly divided into five groups of five rats each. All treatments were 
done orally daily for 6 weeks. The time difference between MEVd and cadmium administration was 6 hours daily. The different dosage of MEVd adopted was to determine the more effective dose.

Group I served as control and received I ml distilled water. Group II received only Cadmium $(10 \mathrm{mg} / \mathrm{kg}$ b.wt). Group III rats were treated with MEVd (200 $\mathrm{mg} / \mathrm{kg}$ b.wt and Cadmium $(10 \mathrm{mg} / \mathrm{kg}$ b.wt) at 6 hours interval daily. Group IV rats were treated with MEVd (400 mg/kg b.wt and Cadmium (10 mg/kg b.wt) at 6 hours interval daily. Group V rats received only MEVd (400 mg/kg b.wt) daily.

\section{Animal sacrifice and collection of tissues}

After 6-weeks of treatment, the rats were deprived of food overnight and the following day were anesthetized and sacrificed by jugular puncture. Immediately after the blood was collected, the liver and kidneys were quickly excised, trimmed of connective tissues, rinsed with saline to eliminate blood contamination, dried with blotting paper, weighed (so as to calculate the relative weight) and stored in $10 \%$ formalin for histological investigation.

\section{Preparation of serum}

The blood samples collected into plain sample tubes were allowed to clot and the serum separated by centrifugation at $1000 \mathrm{~g}$ for 15 minutes using a centrifuge (Surgifriend Medicals SM800B, England). The clear supernatant, the serum, was used for the assay of biochemical parameters.

\section{Determination of biochemical parameters}

The Serum creatinine concentration was determined according to the colourimetric method of Bartels and Bohmer (1973). The serum urea levels was determined by the method Berthelot's reaction (Fawcett and Scout, 1960). Sodium ion in serum was determined using the method of Trinder (1951) and Maruna (1958). Serum Potassium ion concentration was determined using the method of Terri and Sesin, (1958). The concentration of serum Chloride ion was determined using the method of Skeggs and Hochstrasser (1964). The determination of serum ALT and AST activities was carried out as outlined in Randox kits. The serum Total bilirubin concentration was determined according to the method described by Sherlock (1951) as outlined in Randox Kit.

\section{Histological examination}

The histopathology of the tissues of the kidney and liver of the rats was done using the method of Drury and Wallington (1980).

\section{Statistical analysis}

All data were expressed as mean \pm SD $(n=5)$. The statistical significance was evaluated by one-way analysis of variance (ANOVA) and individual comparisons were obtained by Duncan's multiple range test (DMRT) using SPSS (V. 20.0, Chicago, USA). Values were considered statistically significant when $p \angle 0.05$.

\section{Results}

\section{Percentage yield of extract}

The percentage $(\%)$ yield of the methanol leaf extract of Vitex doniana was $8.25 \%$.

\section{Effect of MEVd on body weight of Cadmium} administered rats

Administration of Cadmium chloride significantly ( $p$ $<0.05$ ) retarded the growth (body weight gain) and increased the kidney weight of the experimental animals when compared with the distilled water treated /control animals (Figure 1). However, administration of all the doses of the extract of $V$. doniana significantly $(p<0.05)$ increased the body weight and decreased the kidney weight of the cadmium chloride administered animals towards the control value. It is worthy of note that there was a significant difference $(p<0.05)$ in the body weights of the apparently normal animals that were administered only the higher dose $(400 \mathrm{mg} / \mathrm{kg}$ body weight) of the plant extract when compared with the distilled water administered animals (control).

\section{Effect of MEVd on kidney function parameters of Cadmium administered rats}

Administration of Cadmium chloride significantly ( $p$ $<0.05$ ) increased the urea, creatinine, $\mathrm{K}^{+}, \mathrm{Na}^{+}$and $\mathrm{Cl}^{-}$ concentrations in the serum of the animals when compared with the distilled water treated control animals (Table 2). The administration of all the doses of the extract significantly $(p<0.05)$ ameliorated and in some cases restored the trend of these Cadmium induced alterations in the biochemical parameters towards the control values (Table 2). 
International Journal of Trend in Scientific Research and Development (IJTSRD) ISSN: 2456-6470

Effect of MEVd on liver function parameters of Cadmium administered rats

Furthermore, the same Cadmium administration significantly $(p<0.05)$ increased the activities of AST and ALT, and total bilirubin concentration in the serum of the animals. The administration of all the doses of the extract significantly $(p<0.05)$ ameliorated and in some cases restored the trend of these cadmium induced alterations in the biochemical parameters towards the control values (Table 3 ).

Table 1: Effects of Vd on the body and kidney weight of Cadmium administered rats

\begin{tabular}{|c|c|c|c|c|c|}
\hline \multirow{2}{*}{ Treatments } & \multicolumn{2}{|c|}{ Body weight (BW) } & \multirow{2}{*}{ BW gained (g) } & \multirow{2}{*}{$\begin{array}{l}\text { Kidney weight } \\
\text { (g) }\end{array}$} & \multirow{2}{*}{$\begin{array}{l}\text { Body-kidney } \\
\text { weight ratio }\end{array}$} \\
\hline & Initial BW (g) & Final BW (g) & & & \\
\hline Control & $160.66 \pm 1.96$ & $254.57 \pm 22.40$ & $92.93 \pm 14$ & $0.88 \pm 0.01$ & 289.28 \\
\hline $\mathrm{Cd}$ (10mgkg ${ }^{-1}$ b.w.) & $177.21 \pm 7.72$ & $201.76 \pm 6.49$ & $24.62 \pm 1.79$ & $1.09 \pm 0.01$ & 185.10 \\
\hline $\begin{array}{l}\mathrm{Vd}\left(200 \mathrm{mgkg}^{-1}\right. \\
\text { b.w) }+ \text { Cd }\end{array}$ & $168.81 \pm 7.73$ & $242.27 \pm 19.68$ & $77.47 \pm 8.73$ & $0.90 \pm 0.02$ & 269.19 \\
\hline $\begin{array}{c}\mathrm{Vd}^{\left(400 \mathrm{mgkg}^{-1}\right.} \\
\text { b.w) }+\mathrm{Cd}\end{array}$ & $166.96 \pm 8.57$ & $228.45 \pm 6.89$ & $61.49 \pm 4.28$ & $0.91 \pm 0.02$ & 251.04 \\
\hline $\begin{array}{l}\mathrm{MEVd}^{\left(400 \mathrm{mgkg}^{-1}\right.} \\
\text { b.w) only }\end{array}$ & $168.46 \pm 7.32$ & $245.57 \pm 17.84$ & $81.17 \pm 9.60$ & $0.89 \pm 0.01$ & 275.92 \\
\hline
\end{tabular}

Table 2: Effect of Vitex doniana leaf extract on kidney function of Cadmium administered rats

\begin{tabular}{|c|c|c|c|c|c|}
\hline Treatment group & Urea $(\mathrm{mmol} / \mathrm{L})$ & $\begin{array}{c}\text { Creatinine } \\
(\mu \mathrm{mol} / \mathrm{L})\end{array}$ & $\mathrm{K}^{+}(\mathrm{mmol} / \mathrm{L})$ & $\mathrm{Na}^{+}(\mathrm{mmol} / \mathrm{L})$ & $\mathrm{Cl}^{-(\mathrm{mmol} / \mathrm{L})}$ \\
\hline Control & $2.04 \pm 0.03$ & $56.76 \pm 7.38$ & $5.43 \pm 0.99$ & $84.01 \pm 2.36$ & $66.70 \pm 1.50$ \\
\hline $\mathrm{Cd}(10 \mathrm{mg} / \mathrm{kg}$ b.w $)$ & $9.65 \pm 0.09$ & $130.79 \pm 7.03$ & $7.39 \pm 1.08$ & $159.02 \pm 7.53$ & $\begin{array}{c}116.41 \pm \\
1.04\end{array}$ \\
\hline $\begin{array}{c}\mathrm{Vd}(200 \mathrm{mg} / \mathrm{kg} \\
\text { b.w }+\mathrm{Cd}\end{array}$ & $6.48 \pm 0.04$ & $33.06 \pm 2.14 \mathrm{~m}$ & $3.87 \pm 0.66$ & $137.89 \pm 1.23$ & $73.67 \pm 5.59$ \\
\hline $\begin{array}{c}\mathrm{Vd}(400 \mathrm{mg} / \mathrm{kg} \\
\text { b.w }+\mathrm{Cd}\end{array}$ & $4.15 \pm 0.05$ & $32.63 \pm 8.47$ & $3.89 \pm 0.89$ & $71.78 \pm 1.05$ & $66.96 \pm 7.07$ \\
\hline $\begin{array}{c}\mathrm{Vd}(400 \mathrm{mg} / \mathrm{kg} \\
\text { b.w }) \text { only }\end{array}$ & $2.32 \pm 0.04$ & $60.24 \pm 8.47$ & $2.84 \pm 0.43$ & $79.43 \pm 1.50$ & $64.78 \pm 6.39$ \\
\hline
\end{tabular}

Table 3: Effect of Vitex doniana leaf extract on liver function of Cadmium administered rats

\begin{tabular}{|c|c|c|c|}
\hline Treatments & AST (U/L) & ALT (U/L) & Total- bil. $(\mu \mathrm{mol} / \mathrm{L})$ \\
\hline Control & $10.85 \pm 1.16$ & $4.61 \pm 0.59$ & $6.92 \pm 0.13$ \\
\hline $\mathrm{Cd}\left(10 \mathrm{mgkg}^{-1}\right.$ b.w. $)$ & $52.38 \pm 2.54$ & $83.51 \pm 5.34$ & $21.98 \pm 2.36$ \\
\hline $\mathrm{Vd}\left(200 \mathrm{mgkg}^{-1}\right.$.b.w) $+\mathrm{Cd}$ & $16.95 \pm 2.39$ & $37.51 \pm 2.54$ & $6.71 \pm 0.86$ \\
\hline $\mathrm{Vd}\left(400 \mathrm{mgkg}^{-1}\right.$ b.w $)+\mathrm{Cd}$ & $16.07 \pm 1.45$ & $26.67 \pm 2.30$ & $12.22 \pm 0.37$ \\
\hline $\mathrm{Vd}\left(400 \mathrm{mgkg}^{-1}\right.$ b.w. $)$ only & $13.75 \pm 2.55$ & $5.53 \pm 0.21$ & $7.22 \pm 0.84$ \\
\hline
\end{tabular}

\section{Histopathology}

Effect of MEVd on Histology of Liver and Kidney

Tissues of Cd-Induced Rats 


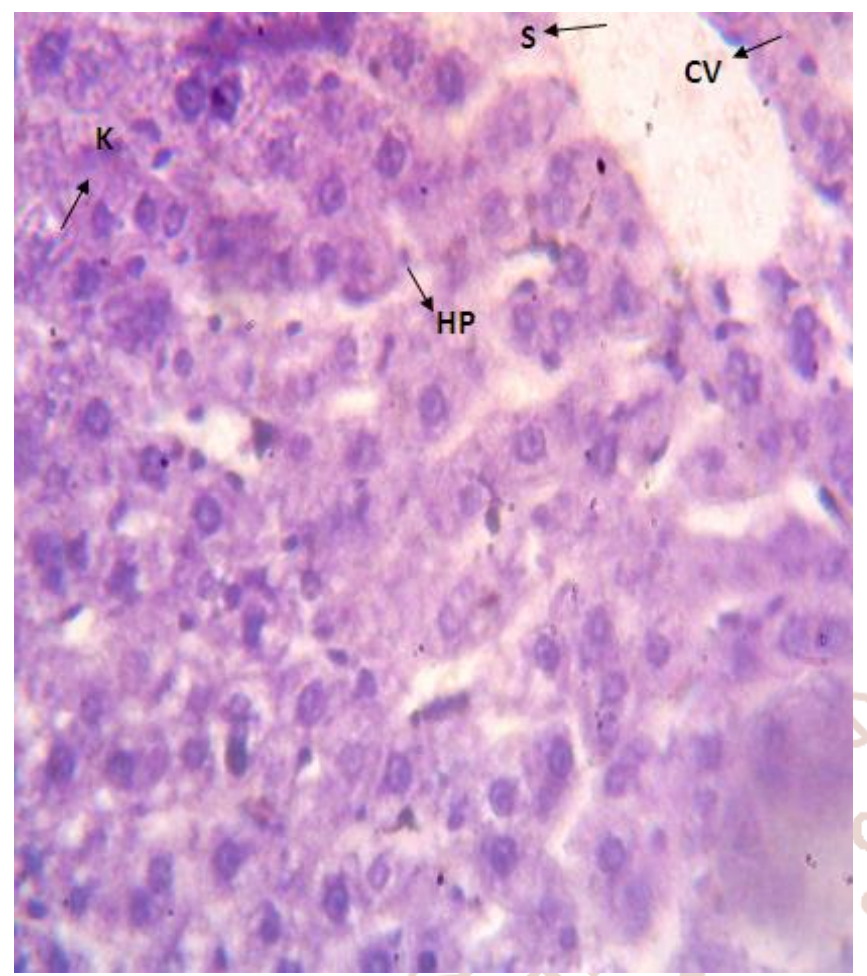

Plate 1: Cross section of liver of male rats orally administered distilled water.

(H \& E; mg x200)

HP: hepatocytes; K: kupffer cells; S:sinusoid, CV: central vein

Plate 1: The histology of the liver of rats administered distilled water showed normal hepatocytes, kupffer cells and sunosoid opening to the central vein, and showed normal lobular architecture.

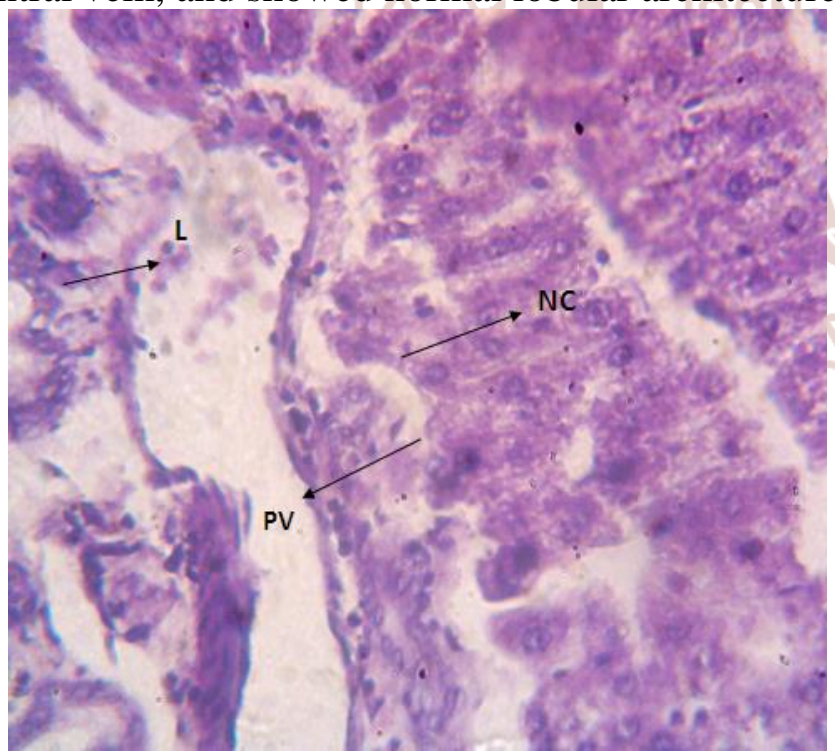

Plate 2: Cross section of liver of male rats orally administered cadmium chloride only

(H \& E; mg x200)

$\mathrm{NC}=$ Necrosis $; \mathrm{PV}=$ Portal vein $; \mathrm{L}=$ Inflammatory lymphocytes.
Histological examination at the end of six weeks (45 days) period of cadmium chloride administration caused severe liver damage including loss of hepatic architecture, necrosis and infilteration of inflammatory cells in the portal vein

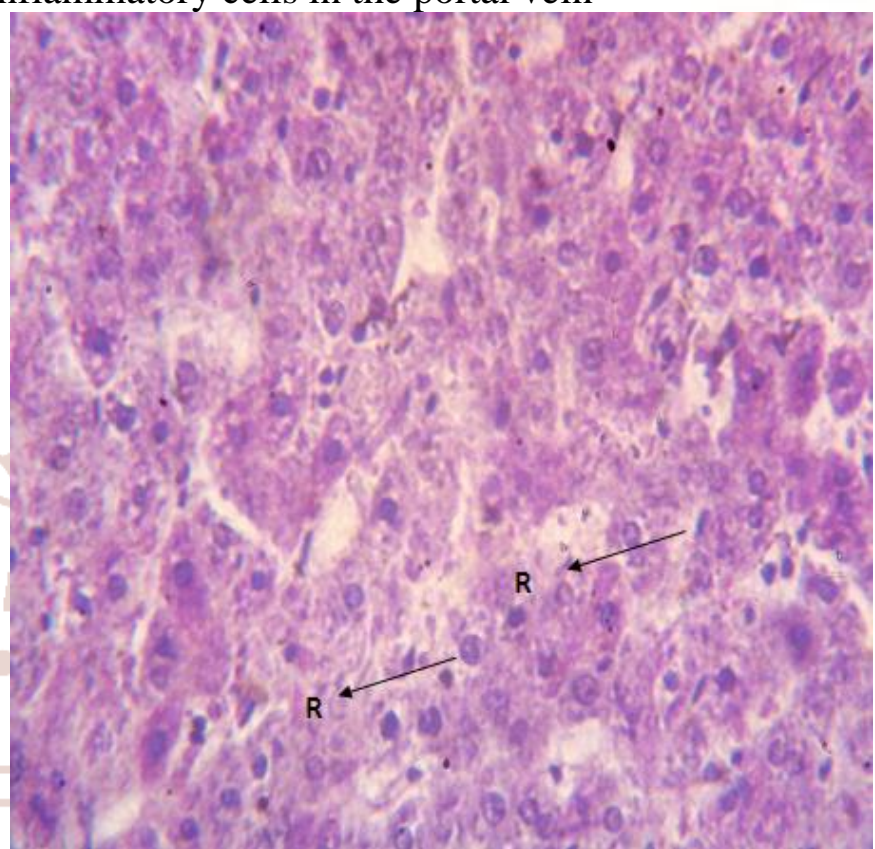

Plate 3: Cross section of liver of male rats orally administered cadmium (10 mg/kg body weight) and treated with the plant extract $(200 \mathrm{mg} / \mathrm{kg}$ body weight)

(H \& E; mg x 200)

$\mathrm{R}=\mathrm{Re}$-epithelization

Histological examination at the end of six weeks (45 days) period of cadmium chloride administration and co-treatment with the plant extract $(200 \mathrm{mg} / \mathrm{kg}$ body weight) showed restoration of the normal architecture of the liver marked by re-epithelization of the tissues.

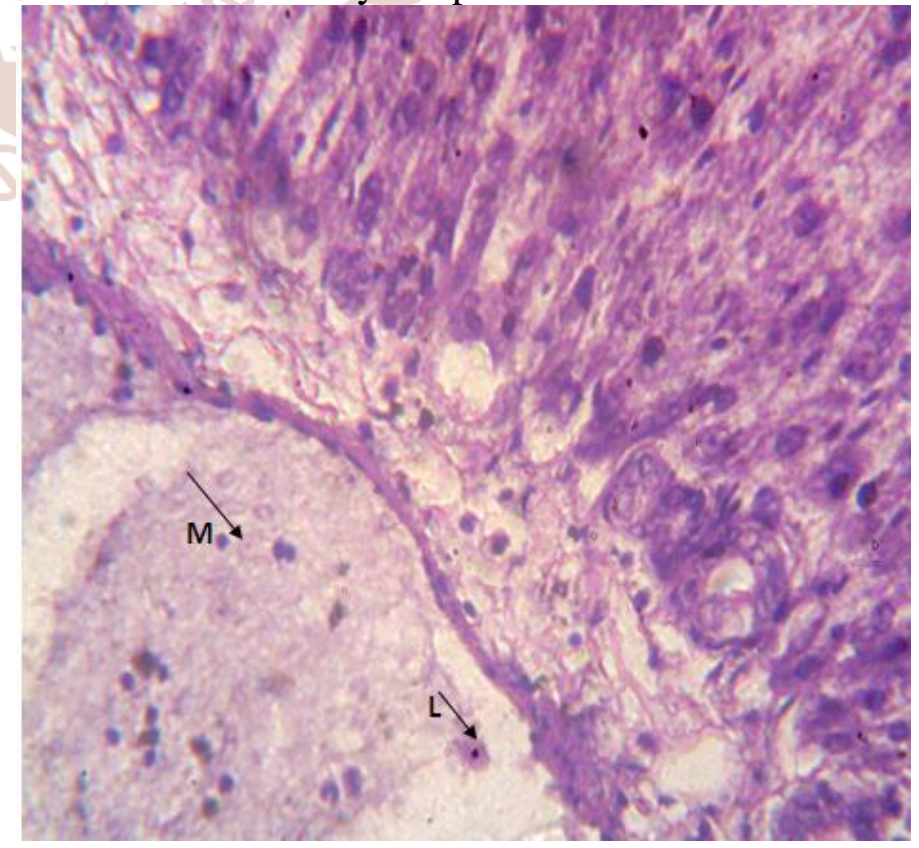


Plate 4: Cross section of liver of male rats orally administered MEVd (400 $\mathrm{mg} / \mathrm{kg}$ body weight) and cadmium chloride

(H \& E; mg x200)

$\mathrm{M}=$ Macrophages; $\mathrm{L}=$ lymphocytes (L)

Histological examination at the end of six weeks (45 days) period of cadmium chloride administration and co-treatment with the plant extract $(400 \mathrm{mg} / \mathrm{kg}$ body weight) showed mild improvement of the architecture of the liver given the infilteration of macrophage and lymphocyte in the portal vein compared with the rats administered $1 \mathrm{ml}$ distilled water (control).

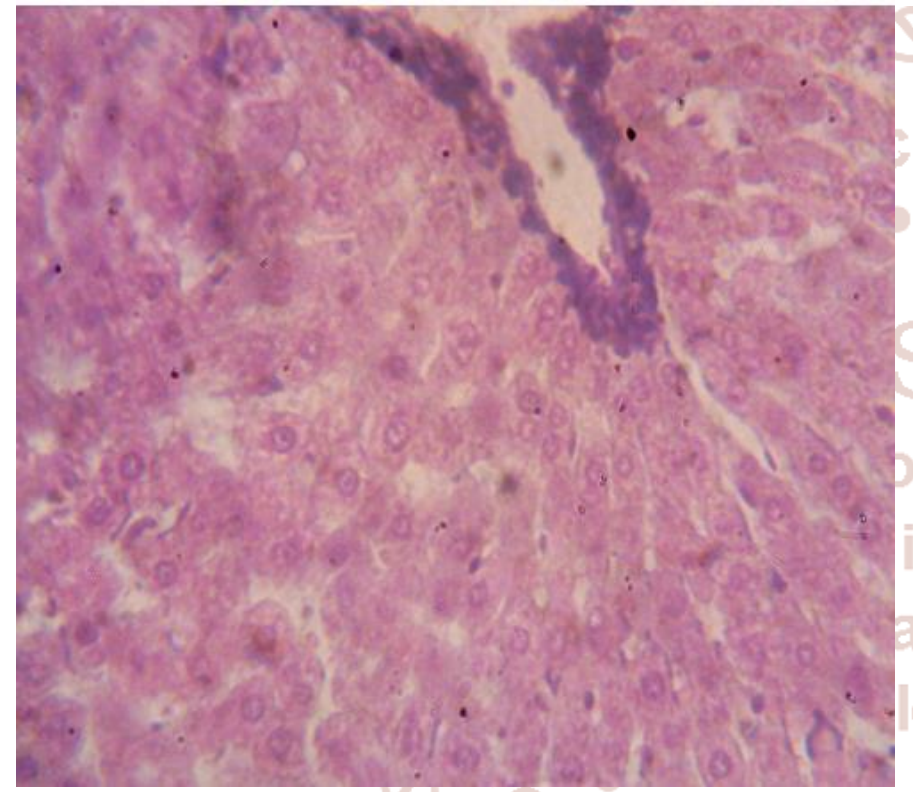

Plate 5: Cross section of liver of male rats orally administered MEVd (400 mg/kg body weight) only

(H \& E; mg x200)

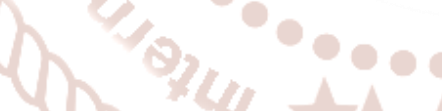

Section of rat liver administered $400 \mathrm{mg} / \mathrm{kg}$ body of methanol leaf extract showed normal architecture. The sinusoid leading to the central vein which is surrounded by hepatic cords radiating towards the periphery.

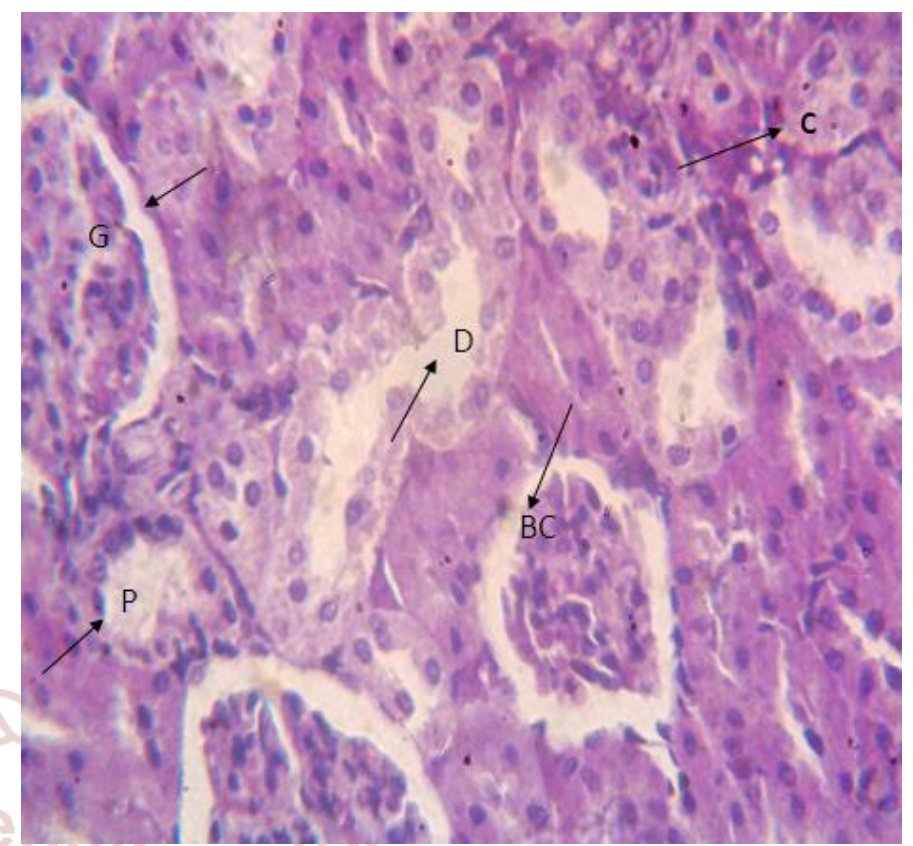

Plate 6: Cross section of kidney of male rats orally administered distilled water

(H \& E; mg x200)

$\mathrm{G}=$ Glomerulus $(\mathrm{G}) ; \mathrm{C}=$ Cuboidal cells; $\mathrm{BC}=$ Bowman's capsule; Distal tubule; $\mathrm{P}=$ Proximal tubule.

The kidney of rats administered distilled water (control) revealed the normal histological structure of the renal tissue. The renal corpuscle consisted of tuft of glomeruli (blood capillaries) surrounded by the Bowman's capsule. The renal tubules included proximal convoluted tubules, lined by large pyramidal cells with brush border and distal convoluted tubules lined by cuboidal cells.

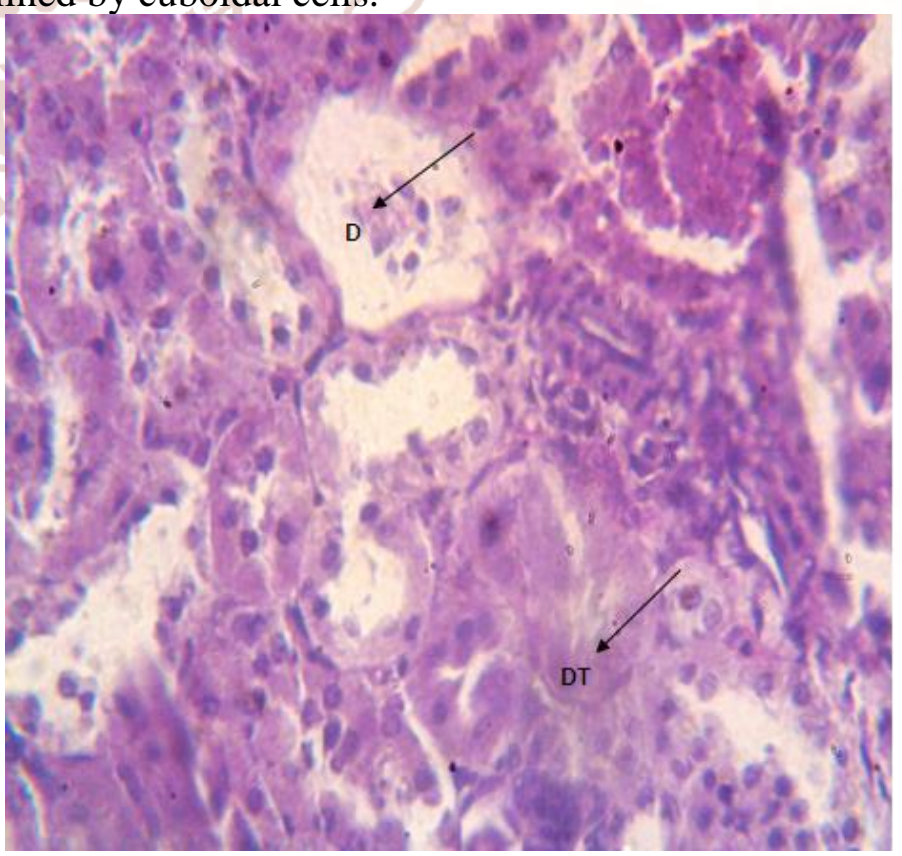


Plate 7: Cross section of kidney of male rats administered Cadmium (10 mg/kg body weight) only)

(H \& E; mg x200)

DT $=$ Deletion of tubular component $; \mathrm{P}=$ Proximal and distal tubular necrosis; $\mathrm{D}=$ dissolution of tuft of glomerulus.

Histological examination of the kidney of rats at the end of six weeks (45 days) period of Cadmium chloride administration showed histopathological changes including dissolution and shrunken of tuft of glomeruli, and tubular necrosis.

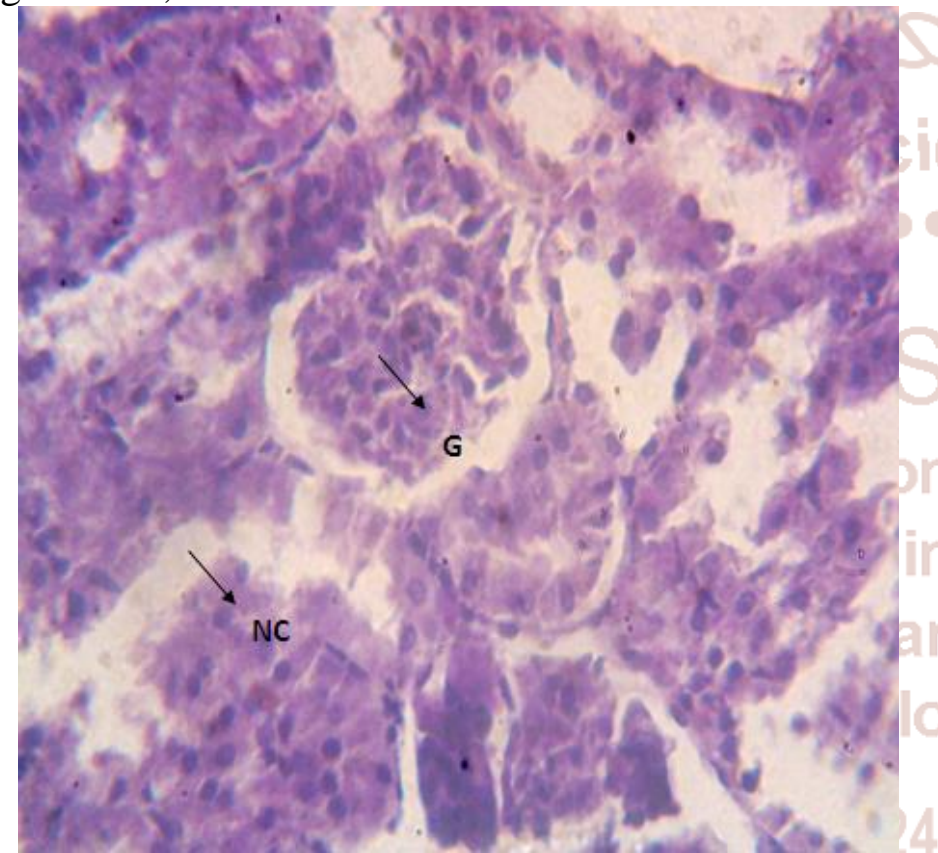

Plate 8: Cross section of kidney of male rats administered MEVd (200 $\mathrm{mg} / \mathrm{kg}$ body weight) and Cadmium (10 mg/kg body weight)

(H \& E; mg x200)

$\mathrm{G}=$ Intact glomerulus

Cross section showed that the pathological changes (dissolution and shrunken of tuft of glomeruli, and tubular necrosis) elicited by cadmium were remarkably reduced, since the glomeruli and renal tubules appeared similar to the control.

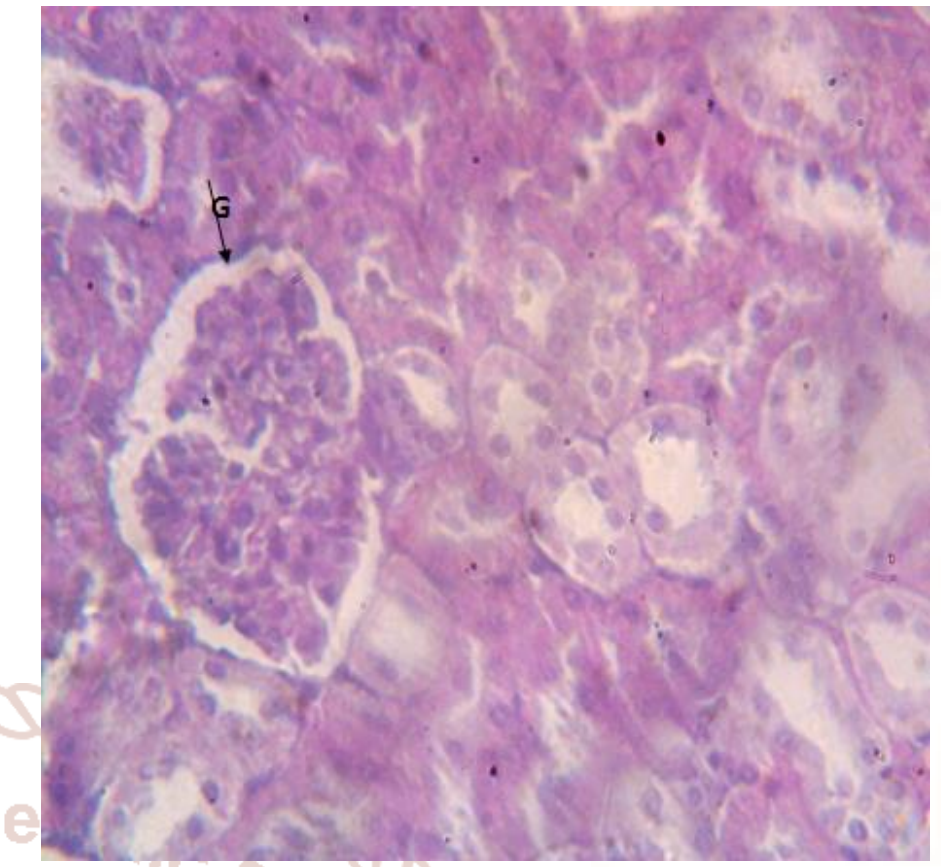

Plate 9: Cross section of kidney of male rats administered MEVd (400 mg/kg body weight) and Cadmium (10 mg/kg body weight)

(H \& E; mg x200)

$\mathrm{G}=$ Intact glomerulus

Histological examination of the kidney of rats at the end of six weeks (45 days) period of MEVd (200 $\mathrm{mg} / \mathrm{kg}$ body weight) showed that the pathological changes (dissolution and shrunken of tuft of glomeruli, and tubular necrosis) elicited by cadmium were partially reduced compared to the control.

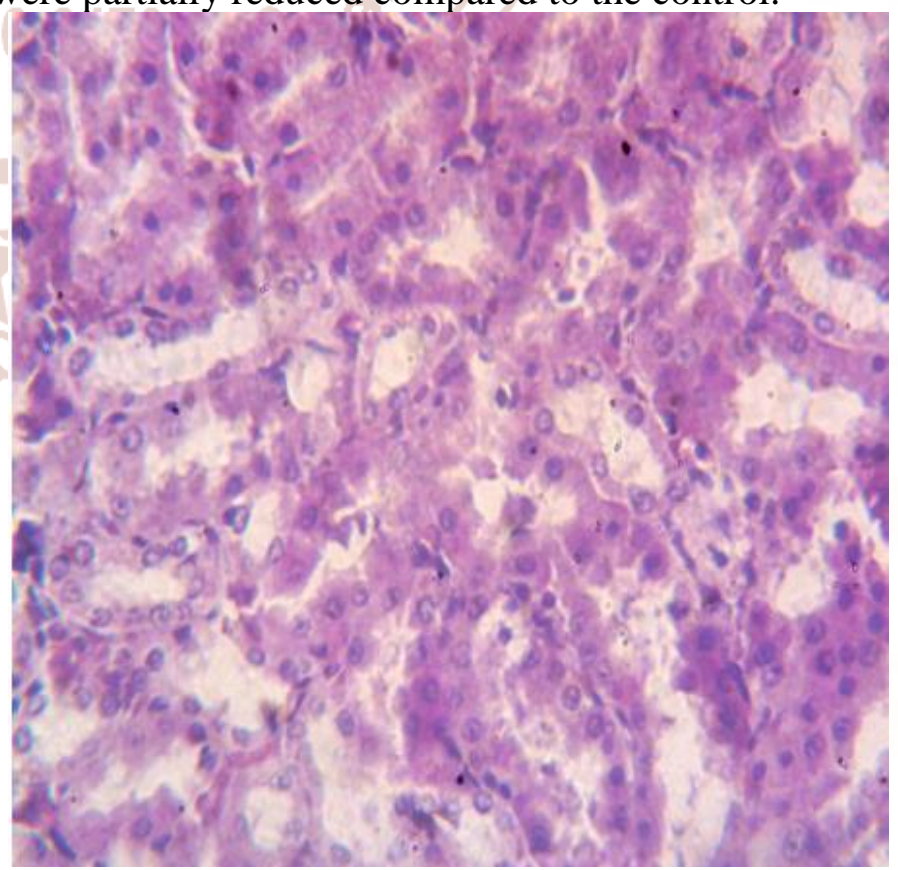

Plate 12: Cross section of kidney of male rats administered MEVd (400 mg/kg body weight) only

(H \& E; mg x200) 
Histological examination of the kidney of rats administered the higher dose of leaf extract of Vitex doniana (400 mg/kg body weight) for six weeks (45 days) period showed that the plant extract had no damaging effect on the kidney.

\section{DISCUSSION}

Numerous animal models have been developed in the past few decades for studying heavy metal induced toxicity on which the efficacy of chemical compounds including phyto-chemicals and its products as ameliorative agent(s) can be evaluated.

Cadmium is a heavy metal known for its notorious role in environmental and industrial pollution which result in deleterious effects on humans and animals. Chronic exposure to Cadmium is known to cause damage to several systems and soft tissues including the kidney and liver. However the kidney is the primary target of Cadmium intoxication (Satarug et al., 2003). Therefore, the need to document agents/compounds including medicinal plants that mitigate or ameliorate this cadmium-induced toxicity cannot be overemphasized.

Six-weeks following cadmium administration, the growth (increase in body weight) of the animals was significantly retarded. Weight loss of cadmium administered rats have been linked to serum proteins reduction and severe diarrhea. It has been reported that cadmium inhibits growth (El-Demerdash et al, 2004). The increase in the kidney weight of rats administered cadmium only was caused by the retarded growth and maybe hypertrophy elicited by the renal toxicity due to cadmium exposure and cadmium accumulation in the kidney (Babaknejad et $a l, 2015)$. Exposure to heavy metal such as cadmium is damaging to glucocorticoids. The glucocorticoid hormones are pivotal in glucose regulation and also in carbohydrate, lipid and protein metabolism. Glucocorticoid dysfunction is associated with weight gain or loss (Ojo et al, 2014)

Serum urea and creatinine concentrations are employed for estimating renal glomerular function. According to the report of Chawla (2003), elevated levels of serum urea and creatinine are associated with kidney disease. Urea is the major nitrogenous end product of protein catabolism, and the major constituent of the total urinary nitrogen excretion. For this reason serum urea and creatinine levels were assayed. In the present study, the elevated levels of urea and creatinine by the Cadmium suggest dysfunction in the kidney by the toxic metal, also similar elevations in the serum electrolytes $\left(\mathrm{Na}^{+}, \mathrm{K}^{+}\right.$ and $\mathrm{Cl}^{-}$) indicates adverse effects on the tubular reabsorption of the electrolytes. These effects may be associated with the changes in the threshold of tubular reabsorption, renal blood flow, and glomerular filtration rate (Ojo et al., 2014). It is reported that increased serum urea concentration is an indication of reduced glomerular filtration rate in rats exposed to cadmium (Satarug and Moore, 2004). In addition, it is also proposed that Cadmium exert a direct toxicity on the glomeruli, thereby causing a decreased clearance of urea and creatinine (Noonan et al., 2002). In this study, the methanol leaf extract of $V$. doniana had an ameliorating effect against cadmium-induced toxicity in kidney, as established by the significant decrease in urea and creatinine levels in the Cadmium-exposed rats co-treated with $V$. doniana compared with cadmium-alone group. The reabsorption of these biomolecules and electrolytes were facilitated by all the doses of the extract.

Increased activities of serum AST and ALT are considered to be proven indicators of hepatocellar damage. Given the antioxidant/oxidant ratio in liver cells, the levels of the hepatic enzymes, AST and ALT activities may reflect liver tissue damage maybe by a distorted cell membrane permeability which results in the leakage of the enzymes from hepatic tissue to the serum (Adefegha et al., 2015). Findings from this study revealed that there was a serious necrotic hepatic damage which significantly increased the activities of AST and ALT in the serum of the cadmium intoxicated rats when compared with the normal rats administered distilled water (control group). Since the liver is the major organ responsible for the detoxification and transformation of most xenobiotics, its regulating mechanism is compromised due to accumulation of toxicants thereby leading to the tissue damage (Camargo and Martinez, 2006). The ameliorative effect of $V$. doniana on cadmiuminduced hepatotoxicity may be due to the antioxidant and inti-inflammatory activities of $V$. doniana as reported by Yakubu et al (2013) and Iwueke et al (2006) respectively. The serum total bilirubin is also one of the major indices used to assess liver function as well as disease progression (Uthandi and Ramasamy, 2011). In this study, the elevated serum total bilirubin of cadmium administered rats was completely reversed by the oral administration of the lower dose of theleaf extract. 
In all, the methanol leaf extract of Vitex doniana ameliorated the cadmium chloride- induced toxicity in the liver and kidney of male Wistar rats. This was evident in the significant reduction in all the elevated biochecal parameters due to cadmium toxicity and the obvious restoration of the architecture of the liver and kidney of the rats as shown in the histopathology results.

\section{REFERENCES}

1. Adefegha, S. A., Omojokun, O. S. and Oboh, G. (2015). Modulatory effect of protocatechuic acid on cadmium induced nephrotoxicity and hepatotoxicity in rats in vivo. SpringerPlus, 4:619. DOI 10.1186/s40064-1408-6.

2. Agbafor, K. N. and Nwachukwu, N. (2011). Phytochemical analysis and antioxidant property of leaf extract of Vitex doniana and Mucuna pruriens. Biochemistry Research International. 1: $1-4$.

3. Al-Hashem, F., Dallak, M., Bashir, N., Abbas, M., Elessa, R., Khalil, M. and Al-Khateeb, M. (2009). Camel's milk protects against cadmium chloride induced toxicity in white albino rats. American Journal of Toxicology, 4(3): 107-117.

4. Atawodi, S. E., Bulus, T., Ibrahim, S., Ameh, D. A., Nok, A. J., Mamm N, M., and Galadima, M. (2003). In vitro trypanocidal effect of methanol extract of some Nigerian Savannah plants. Afr. J. Biotech. 2(9): 312-321.

5. Babaknejad, N., Mashtaghie, A. A., Shahanipour, K., and Bahrami, S. (2015). The protective roles of Zinc and Magnesium in Cadmium-induced renal toxicity in male Wistar rats. International Journal of Toxicology, 8(27): 1160-1167.

6. Bartels, H. and Bohmer, M. (1973). A kinetic method for measurement of serum creatinine. Medicine Laboratory, 26(9): 209-215.

7. Burkill, H. M. (2000). Useful Plants of West Tropical Africa. Second edition, volume 5, Royal Botanic Garden Kewer, Page 272-275.

8. Camargo, M. M. and Martinez, C. B (2006). Biochemical and physiological biomarkers on Prochilodus lineatus submitted to in situ test in an urban stream in southan Brazil. Environ Toxicol Pharmacol, 21: 61-69.

9. Chawla, R. (2003). Practical clinical biochemistry: Methods and interpretation. New Delhi (India): jaypee Brothers Publishers.
10. Drury, R. A., Wallington, A. and Cameroun, S. R. (1967). In Carlleton's Histhological Techniques. Oxford University Press, New York. Pp 1-420.

11. El-Demerdash, F. M., Yousef, M. I., Kedwany, F. S., and Baghdadi, H. H. (2004). Cadmium induced changes in lipid peroxidation, blood hematology, biochemical parameters and semen quality of male rats: protective role of vitamin $\mathrm{E}$ and $\beta$-carotenr. Food and chemical toxicology, 42(10): 15631571 .

12. Fawcett, J. K. and Scott J. (1960).A rapid and precise method for the determination of urea. Journal of Clinical Pathology, 13(2): 156-159.

13. Iwu, M. M. (1993). Handbook of African medicinal plants. CRC Press, London.

14. Iwueke A V, and Nwodo O F C, Okoli C O. (2006). Evaluation of the anti-inflammatory and analgesic activities of Vitex doniana leaves. Afric J Biotech. 5(20):1929-1935.

15. Jarup, L., Hellstrom L., Alfven T., Carlsson M. D., Grubb A., Persson B. (2000). Low level exposure to cadmium and early kidney damage. The OSCAR Study. Occup Environ Med. 57: 668-672.

16. Maruna, R. F. L. (1958). Colorimetric determination of sodium. Clinical Chemistry. $2: 581$

17. Navaneethan, D. and Rasool, M. K. (2014). An experimental study to investigate the impact of $p$-coumaric acid, a common dietary polyphenol, on cadmium chloride-induced renal toxicity. Food Funct 5: 2438-2445.

18. Noonan C W, Sarasua S M, Campagna D, Kathman S J, Lybarger J A, and Mueller P W (2002). Effects of exposure to low levels of environmental cadmium on renal biomarkers. Environ Health Persp, 110: 151-155.

19. Nnamani, C. V., Oselebe, H. O and Ogbonna, A. N. (2007). Effects of leaf extracts of Dracean aborae L. and Vitex donian Sweet on the larvae of Anopheles mosquito. Animal Research International, 5(2): 184-186.

20. Nwachukwu, E. and Uzoeto O. H. (2010). Antimicrobial activities of leaf of Vitex doniana and Cajanus cajan on some bacteria. Researcher, 2(3): $37-47$. 
21. Ohta, H., Yamauchi, Y., Nakakita, M., Tanaka, H., Asami, S., Seki, Y., et al (2000). Relationship between renal dysfunction and bone metabolism disorder in male rats after lon-term oral quantitative cadmium administration. Industr Health 38: 339-355.

22. Ojo, O. A, Ajiboye B. O., Oyinloye B. E, Ojo A. B., and Olarewaju OI (2014). Protective effect of Irvingia gabonensis stem bark extract on cadmium-induced nephrotoxicity in rats. Interdiscip. Toxicol, 7(4): 208-1242.

23. Satarug, S., Garrett, S. H., Sens, M. A., and Sens, D. A. (2010). Cadmium, environmental exposure, and health outcomes. Environ Health Perspect 118: $182-190$.

24. Satarug, S. and Moore, M. R. (2004). Adverse health effects of chronic exposure to low-level cadmium in foodstuffs and cigarette smoke. Environ Health Persp, 112: 1099-1103.

25. Satarug, S., Baker, J. R, Urbenjapol M, HaswellElkins M, Reilly PE, Williams DJ and Moore, M.R. (2003). A global perspective on cadmium pollution and toxicity in non-occupationally exposed population. Toxicol Lett 137; 65-83.

26. Sherlock, S. (1951). The liver in heart failure relation of anatomical, functional and circulatory changes. British heart journal, 13(3): 273-293.
27. Skeggs, L. T. and Hochstrasser, H. C. (1964). Colorimetric Determination of Chloride. Clinical Chemistry, 10:918.

28. Terri, A. E. and Sesin, P. G. (1958). Colorimetric Determination of Potassium. American Journal of Clinical Pathology, 29:86.

29. Trinder, P. (1951). Colorimetric Determination of Sodium. Analyst, 76:596.

30. Uthandi, A and Ramasamy K (2011). Hepatoprotective activity of Sesame meal on high fat fed Wistarrats. International Journal of Pharmaceutical Science, 2(12): 205-211.

31. Waisberg, M., Joseph, P., Hale, B., and Beyersmann, D. (2003). Molecular and cellular mechanism of cadmium carcinogenesis. Toxicology 192: 95-117.

32. Yakubu, O. E., Ojogbane, E., Nwodo, O. F. C., Nwaneri-Chidozie, V. O. and Dasofunjo, K. (2013). Comparative antioxidant and hypoglycaemic effects of aqueous, ethanol and $n$ hexane extracts of leaf of Vitex donianaon streptozotocin induced diabetes in albino rats. African Journal of Biotechnology, 12(40): 59335940. 